\title{
The Effect of Using Course Review Horay and Talking Stick Learning Methods Towards Social Science Learning Result Reviewed From Learning Interest
}

\author{
Bety Ratih Meganingtyas ${ }^{1}$, Retno Winarni², Tri Murwaningsih ${ }^{3}$
}

\section{ARTICLE INFO}

\section{Article History:}

Received 09.09.2018

Received in revised form

05.01.2019

Accepted

Available online 01.04.2019

\begin{abstract}
The research aims at: first the effects of Course Review Horay and Talking Stick learning methods towards Social Science learning result.; second the effect of high or low learning interest to wards Social Science learning result; third the interac tion effect between Course Review Horay and Talking Stick learning methods and Social Science learning result. The research population is all students of grade V at SD Negeri Kecamatan Kedung galar, Ngawi, East Java, in Academic Year 2017/2018. The research uses stratified cluster random sampling. The samples are 101 students which consists of 50 students for experimental class and 51 students for control class. The research instruments are social science test result and questionnaire of students' learning interest.Hy pothesis testing uses variance analy sis (anava) with two different cell paths. The research conclusion is as follows: first, there is an effect of Course Review Horay and Talking Stick learning methods to wards Social Science learning result, second there is an effect between students who have high or low learning interest and Social Science learning result, third there is no interaction between course review horay and talking stick learning methods and learning interest. Social science learning result using course review horay learning method is better than social science learning result using talking stick learning method. Students are advised to be confident in participating in classroom learning. Students who actively participate during the learning process, so that students can understand meaning fully the material presented by the teacher.
\end{abstract}

(C) IJERE. All rights reserved

Keywords:

Course Review Horay, talking stick, social science learning result, learning intreset.

\section{INTRODUCTION}

A research done by Gull \& Shexad (2015) states that the main goal of learning process is to get scores, since it is considered as the measure of success of learning. Students assume that a score is the main thing which they should achieve, as the teachers do. The teachers eagerly try to make their students be smart. Teachers' objective to make the students be smart causes them to neglect learning process which should make the students have good attitude and skills.

Learning has a really important role in life, either for human or other living creatures. Learning becomes the basic thing for life sustainability because it will keep moving on greatly if its living creatures have willingness to learn properly. Bow er and Hirlgarad (1981) explain that learning is achieving knowledge by experiencing, recalling, mastering, and obtaining or discovering the information; moreover, it can also be stated that learning is the activity of mastering a particular thing. Learning is not only a process of transferring knowledge from a teacher to students, but a process of material absorption significantly by the students, a process of cooperating and respecting other students and a process of actively participating based on class regulation. Students is an individual who has readiness to accept any information and knowledge from various sources. Students have an ability to absorb any information that they get, without considering where it comes from. The teachers should act as facilitators who facilitate the student $s$ to look for information from other sources or people.

Education is a basic need that absolutely necessary for all levels society (Purwanti, et. al., 2018). Maria Montessori in Hainstock (1999) reveals that education is the self-activity leading to build the personal discipline, independence, and self-instruction. Thus, it must be supported by learning as a part of education. Learning is a process when the students start absorbing all information relating to learning material. The process of information absorption should be done by considering students' characteristics. Based on the result of observation and interview which is done at Kawu 1 elementary school during social science

\footnotetext{
${ }^{1}$ Corresponding e-mail: betyratih1991@gmail.com ; orcid.org/0000-0003-4122-5751

${ }^{1}$ student of Master Program of Elementary School Teacher Education, Sebelas Maret University

${ }^{23} 2$; orcid.org/0000-0003-1110-6890

3;orcid.org/0000-0001-8266-6815

lecturer of Master Program of Elementary School Teacher Education, Sebelas Maret University
} 
Meganingtyas,B.R., Winarni,R. \& Murwaningsih,T.(2019).The effect of using course review horay and talking stick learning methods towards social science learning result reviewed from learning interest.International Journal of Educational Research Review,4(2), 190-197.

learning process, it shows that learning process done in the class does not stimulate the students to actively participate, either in written or spoken form. Students sometimes work alone and compete to get the best score, praise and teacher's acknowledgement. Students' selfishness can give bad effects to students' psychology and class condition. Students who have better competence tend to be arrogant and disparage students who have less competence. Meanwhile, students who have less competence will be inferior since no matter how much effort they give, they cannot achieve the same achievement as their friends who have better competence.

Agus Suprijono (2010) explains that there are two learning objectives: instructional effects and nurturant effects. The explicit learning objective is achieved by the instructional acts which are commonly known as instructional effects in the form of knowledge and skill. Meanwhile, the learning objectives which are in the form of the result accompanying the instructional learning objective are commonly known as nurturant effects. The form of nurturant effects is the ability to think critically and creatively, open-minded and democratic, and accept others, etc. The objective of learning is to make the individuals have an ability to think critically, be open and be responsible. This goal cannot be achieved if the teachers still use lecturing method in teaching process. Hamidah et.al. (2018) states that learning material nowadyas becomes the connection between teacher and students where the teachers has a role as a facilitator.

Permendiknas 2006 concerning the Standard of Content explains that the scope of social science subject covers: (a) Human, place, and environment; (b) Time, sustainability, and change; (c) Social and cultural system; and (d) Economic behavior and wealth. Social science is a subject which discusses about time, circu mstance, democracy and any other abstract things. The students need to have highly understanding since there are many things to be learned and remembered, especially for elementary students whose cognitive development is still in concrete operational phase. Based on the discussion abovementioned, teachers need to find learning model to help students understanding Social Science materials.

Cooperative learning can be the solution to create a pleasant learning process. A research done by Nelson, Gallagher and Coleman in Azizinehad et. al. (2013) shows that cooperative learning can be the best option for all students because it can improve the interaction between students, despite of their competence and background. Cooperative learning can make students be able to discuss and to share their opinions to other classmates, as well as to achieve learning goals together. The research result of Hossain and Tarmizi define that cooperative learning has been documented well in educational research as a succeed pedagogy to improve students' achievement. Cooperative learning helps the students to absorb materials significantly which effect is better achievement. Johnson and Johnson in Aziz et. al. (2010) state that cooperative learning directs small groups to cooperate and to maximize their learning competence together with other students. Cooperative learning is learning process which focuses on group w ork to achieve learning goals.

Cooperative learning has several methods. This research uses course review horay and talking stick method. Course review horay is one of cooperative learning types which can improve students' understanding by answering the questions in the box as stated by Sugandi \& Rahayu in Rahimah et.al. (2014). Aksiwi \& Sagoro (2014) state that course review horay is a learning method which examine students' understanding by using the box consisting of numbers of answer where the students should shout 'horay' when they can answer correctly. Course review horay is a learning model which can enhance students' understanding by asking the students to answer the questions in the box.

The next learning model used by the researchers is talking stick. Pamungkas (2015) state that talking stick is a learning model which is done by playing stick-rolling after the students have learned the main material. A research done by Vidiyanti et. al. (2017) state that talking stick is a cooperative learning model which need students' courage to answer the give questions. Talking stick is a cooper ative learning model which show students' courage in answering questions. The student who answers the question will be chosen by using the stick.

Learning model is not the only factor which affects students' learning result, but students' learning interest also becomes an important element in the result. Interest is a will or like of someone towards something. Slameto reveals that interest is not inborn yet it is acquired later. Interest on something is the result of learning that supports another learning. It decribes that the interest can be fostered and developed.Interest is a will which needs to be cared and developed, as well as students' learning interest. It 
is not something which is descended by parents, but it needs to be nicely cared, developed and built by students' parents, teachers and adult people around them. Better learning result of Social Science subject is the main goal of this research. It is a skill which students gain after doing learning activities. Students' learning result becomes one of success indicators in learning process. High scores show students' competence in mastering the materials given by the teacher. It is also a success indicator of teachers' success in conducting teaching-learning process.

\section{METHOD}

This research uses quasi experimental design. Quasi experimental design is a research design which consists of control group, but it cannot fully function in controlling external variables which can affect the research. This research aims at discovering there relation between variables in experimental class and control class. The subject of this research is students in grade $\mathrm{V}$ who come from 4 elementary schools in Kedunggalar District. The subject consist of male and female students. The classes consist of experimental class which is taught by using course review horay learning model and a control class which is taught by using talking stick learning method. This research uses $2 \times 2$ factorial research design. The experimental and control classes are given a attribute variable which is learning interest which differs into high and low learning interest.

Sampling techniques used in this research is stratified cluster random sampling. This technique considers the population as groups. The stages of sampling are done as follows: (a) There are 47 elementary schools in Kedunggalar District which are arranged based on Social Science scores of previous final exam. (b) Those schools are divided into two groups; high groups and low groups. High groups consist of Kawu 1 and Kedunggalar 3, low groups consist of Wonokerto 1 and Bangunrejo Kidul 4. These four schools are later devided into experimental group (Kawu 1 and Wonokerto 1) and control group (Kedunggalar 3 and Bangunrejo Kidul 4). The technique of data collection used in this research is documentation, learning interest questionnaire and test scores. The technique of data analysis uses SPPS 20 software.

\section{RESULT}

\section{Hypothesis Test Result}

Hypothesis test uses two paths anava followed by Scheffe test. A summary result of hypothesis test can be seen in table 1 .

Table 1: Summary of Hypothesis Test Result

\begin{tabular}{c|c|c|c|l|c}
\hline Source & $\begin{array}{c}\text { Type III } \\
\text { Sum of Squares }\end{array}$ & Df & Mean Square & F & Sig. \\
\hline Learning Method & 284,308 & 1 & 284,308 & 4,450 &, 037 \\
Learning Interest & 3475,016 & 1 & 3475,016 & 54,386 &, 000 \\
Learning Method & 85,806 & 1 & 85,806 & 1,343 &, 249 \\
* Learning interest & 6197,814 & 97 & 63,895 & & \\
Error & 501364,000 & 101 & & & \\
Total &
\end{tabular}

a. $\mathrm{R}$ Squared $=, 403$ (Adjusted R Squared $=, 384$ )

The statistics analysis result of two paths anava show F count value of learning method is 4.450 and significance value is 0.037 which is low er than significance level $\alpha=0.05$. It show s that there is a difference or effect of learning method tow ards students learning result in Social Science using course review horay and talking stick. Meanwhile, the statistics analysis result of two paths anava shows that F count is 54.386 with significance value 0.000 which is lower that $\alpha=0.05$. The learning interest analysis shows that there is a difference or effect of learning interest tow ards students learning result in Social Science. The analysis about interaction between learning method and learning interest shows that there is F count value 1.343 and 
significance value 0.249 which is higher that significance level $\alpha=0.05$. It shows that there is no interaction found between learning method and learning interest.

The result of learning method analysis abovementioned is that $\mathrm{H}_{0}$ stating that "there is a difference in Social Science learning result between learning using course review horay and talking sticks methods" is accepted. The result of learning interest analysis is that Ho stating that "there is a difference in Social Science learning result between students who have high and low learning interest" is accepted. The result of interaction analysis between learning method and learning interest shows that Ho stating that "there is effect interaction between the use of Course Review Horay and Talking Stick learning methods and students' learning interest tow ards Social Science learning result" is declined.

\section{Discrepancy Test of Social Science Learning Result of Students Taught by using Course Review Horay and Talking Stick}

Test differences in Social Science learning result of student taught by Course Review Horay and student taught by Talking Stick can be seen from the marginal mean value without having to do a double comparison test. A summary of students' Social Science learning result based on learning method can be seen in table 2.

Table 2: Summary of Students' Learning Result in Social Science based on Learning Method

\begin{tabular}{c|c|c|c|c}
\hline Method & Mean & \multirow{2}{*}{ Std. Error } & \multicolumn{2}{|c}{$95 \%$ Confidence Interval } \\
\cline { 4 - 5 } & & & Lower Bound & Upper Bound \\
\hline CRH & 70,915 & 1,164 & 68,604 & 73,226 \\
\hline TS & 67,508 & 1,120 & 65,286 & 69,730 \\
\hline
\end{tabular}

The table shows that the marginal rate of Social Science learning result using Course Review Horay is 70.92 and the marginal rate of Social Science learning result using Talking Stick is 67.51. The result shows that learning result of student taught by using Course Review Horay is higher or better than them who is taught by using Talking Stick learning method.

\section{Discrepancy Test of Social Science Learning Result of Students Having High and Low Learning Interest}

Test difference in Social Science learning result between student who have high and low learning interest can also be seen from the marginal mean. The summary of students' Social Science learning result based on learning interest can be seen in table 3 .

Table 3: Summary of Students' Learning Result in Social Science view ed from Learning Interest

\begin{tabular}{l|r|r|r|r}
\hline Learning Interest & Mean & Std. Error & \multicolumn{2}{|c}{$95 \%$ Confidence Interval } \\
\cline { 4 - 5 } & & & Lower Bound & Upper Bound \\
\hline Low & 63,255 & 1,206 & 60,861 & 65,649 \\
High & 75,168 & 1,074 & 73,035 & 77,300
\end{tabular}

The table show s that the marginal rate of Social Science Learning Result of students having low learning interest is 63.26 and the marginal rate of them having high learning interest is 75.17 . The result shows that the students who have high learning interest get better score in Social Science than them who have low learning interest. 
Meganingtyas,B.R., Winarni,R. \& Murwaningsih,T.(2019).The effect of using course review horay and talking stick learning methods towards social science learning result reviewed from learning interest.International Journal of Educational Research Review,4(2), 190-197.

\section{Interaction Test between Learning Method and Learning Interest}

Test of interaction between learning method and learning interest can be seen from marginal mean. A summary of the interaction between learning method and learning interest can be seen in table 4

Table 4: Summary of Interaction between Learning Method and Learning Interest

\begin{tabular}{ll|r|r|r|r}
\hline Learning method & Learning Interest & Mean & Std. Error & \multicolumn{2}{|c}{$95 \%$ Confidence Interval } \\
\cline { 4 - 5 } & & & Lower Bound & Upper Bound \\
\hline \multirow{2}{*}{ CRH } & Low & 65,895 & 1,834 & 62,255 & 69,534 \\
& High & 75,935 & 1,436 & 73,086 & 78,785 \\
TS & 60,615 & 1,568 & 57,504 & 63,727 \\
& Low & 74,400 & 1,599 & 71,227 & 77,573
\end{tabular}

The table shows that in course review horay learning, the marginal rate of low learning interest is 65.89 and the marginal rate of high learning interest is 75.94 . Meanwhile, in talking stick learning method shows that the marginal rate of low learning interest is 60.62 and high learning interest is 74.40 .

\section{DISCUSSION}

\section{Students' Learning Result in Social Science based on Learning Method}

Based on description analysis of the average scores of Social Science learning result of students taught by using course review horay is different from them who are taught by using talking stick learning method. The students' average score in Social Science learning result using course review horay is 70.92. Meanwhile, students' average score in Social Science learning result using talking stick is 67.51. This result shows that students who are taught by using course review horay get better Social Science scores than them who are taught by using talking stick learning method. Based on the calculation abovementioned, it can be concluded hat course review horay learning method give more effects than talking stick learning method. Social Science learning result of students who are taught by using course review horay is better than them who are taught by talking stick. It is because course review horay has more strength which stimulates students to work cooperatively and to answer questions, as well as when they are given learning materials. The students working in group more easily understand the material than working alone, thus it gives more positive effects for their Social Science learning result.

The result of the research is in line with the result of the research conducted by Mulyani (2016) stating that the implementation of course review horray is effective on the learning result of social science program. A research done by Anggraeni (2011) shows that students' activity in learning process is improved, as well as the learning quality of Social Science which can be seen from the score improvement in every cycle.

This research does not only show that the students taught by using course review horay get higher score than them who are taught by using talking stick, but also show the problems found during learning process. The implementation of course review horay and talking stick methods have several problems which need to be solved as soon as possible. The problems are found during observation when the teacher conducts a quiz which should be done by students in group. Conducting a quiz requires the teacher to be flexible and be able to waken students' enthusiasm to answer questions or to do cor rection. The teachers in both schools are still awkward in conducting the quiz. The aw kwardness reduces in every cycle, but it still can be felt until the end of cycle. Awkwardness is not the only problem faced by the teachers, but they also cannot conduct the quiz smoothly.

The researchers try to look for its cause by interviewing them in the end learning process. The teacher in Kaw 1 and Wonokerto 1 elementary school give their response dealing with the problem. They state that it $w$ as the first time for them using course review horay learning method. They are not accustomed to use the method since they used to do lecturing method in teaching learning process. They also have not got any training about how to use cooperative learning, especially course review horay learning method. Their 
unpreparedness becomes the main reason of difficulty in implementing course review horay in learning process. They claim that one week is not enough to optimize their learning preparation using course review horay.

The problems in implementing course review method is not only faced by teachers, but so do the students. The students also seem awkward when the lesson is started. The interview conducted for 3 students in every school generates a similar statement: they are shy since it is the first time for them to be taught by using course review horay. All students state that they used to be taught by lecturing method and their teacher hardly asks them to w ork in group. This habit makes them rarely interact $w$ ith their classmat es, so they turn to be individualist.

Teachers who teach using talking stick also face several problems, but they are not as obviously seen as in course review horay. Anyhow, the problems can be seen when the lesson is started. The teachers in both school still seem aw kw ard in delivering learning goals. How ever, soon the teacher can adapt well, especially teacher in Kedunggalar 3 elementary school. Based on observation result, the researchers conduct interview to know about their opinion and problems in implementing talking stick method. Based on the interview with teacher of Kedunggalar 3 and Bangunrejo Kidul 4 elementary school, it shows that talking stick method is something new for the teachers. They used to teach by using lecturing method, even though they sometimes also ask the students to work in group. They believe that talking stick method is a new learning method, since they have not ever used this method before.

These problems need to be solved as soon as possible. The teachers should start moving from their comfort zone by starts using innovative learning, in this case is course review horay and talking stick. They have to reduce the use of lecturing method little by little, since it can make them be the only information source for students. The students should start to adapt to innovative learning and be given information about the stops in course review horay and talking stick methods.

\section{Students' Learning Result in Social Science viewed from Learning Interest}

Student groups based on learning interest without comparing learning method are divided into groups with high and low learning interest. The analysis shows that Social Science score of students who have high learning interest is 75.17 and they who have low learning interest is 63.26. The result shows that students with high learning interest get high or better Social Science score than they who have low learning interest. The result of research done by Budianto (2010) shows that students who have high learning interest get better Social Science score than they who have low learning interest. Hartanto (2011) also states that mathematics learning competence of students who have high learning interest is higher or better than they who have low learning interest.

The students whohave high learning interest results better Social Science score than they who have low learning interest. The result implicitly shows that students having high learning interest also give attention during learning process. The students who have high learning process a re also actively involved in question and answer session and quiz. They also tend to be able to work in groups, or even they help their friends who have difficulties in understanding the materials.

\section{Interaction between Learning Method and Learning Intere st}

The analysis result shows that there is no interaction betw een learning method and learning interest, so the difference in Social Science score based on learning method in each learning interest follows the characteristics in factor effect B (learning interest), so the conclusion can be drawn as follows: (a) Students having high learning interest during course review horay method get better Social Science score than they who have low interest. (b) Students having high learning interest during talking stick method get better Social Science score than they who have low learning interest. The analysis of Social Science learning result reviewed from learning interest follows the characteristic in factor effect A (learning method), can be concluded as follows: (a) Students having high learning interest gets better Social Science score by using course review horay method than they who learn by using talking stick method. (b) Students having low learning interest gets better Social Science score by using course review horay method than they who learn by using talking stick method. 
Meganingtyas,B.R., Winarni,R. \& Murwaningsih,T. (2019).The effect of using course review horay and talking stick learning methods towards social science learning result reviewed from learning interest.International Journal of Educational Research Review,4(2), 190-197.

\section{CONCLUSION AND SUGESSTIONS}

Based on the data analysis result and discussion based on the problem statements, the conclusion can be drawn as follows: first there is an effect of course review horay and talking stick learning methods towards Social Science result; second there is an effect of students' high or low learning interest towards Social Science learning result; third there is no interaction between Course Review Horay and Talking Stick learning methods and Social Science learning result.

Students are advised to be confident in participating in classroom learning. Students who actively participate during the learning process, so that students can understand meaningfully the materi al presented by the teacher.

\section{REFERENCES}

Aksiwi, R. D. \& Sagoro, E. M.(2014). Implementasi Metode Pembelajaran Course Review Horay untuk Meningkatkan Aktivitas dan Hasil Belajar jurnal Penyesuaian. Jurnal Pendidikan Akuntansi Indonesia, 12(1), 36-47.

Anggraeni, D (2011). Peningkatan Kualitas Pembelajaran IPS melalui Model Pembelajaran Kooperatif Tipe Course Review Horay pada Siswa Kelas IV SD Negeri Sekaran 01 Semarang. Jurnal Kependdikan Dasar, vol/issue 1(2), 194-205.

Aziz, Z. \& Anowar H. Md.(2010). A comparison of cooperative learning and conventional teaching on student's achievement in secondary mathematics. Procedia Social and Behavioral Sciences, 9, 53-62.

Azizinezhad, M., Hashemi, M., \& Darvishi, S. (2013). Application of cooperative learning in EFL classes to enhance students' languange learnin. Procedia Social and Behavioral Sciences, 93, 138-141.

Bower, G. H. \& Hilgard, E. R., (1981). Theories of learning. Englew ood Cliffs New Jersey, Prentice Hall.

Budianto, E. (2010). Efektivitas Metode Pembelajaran Kooperatif Tipe Teams Games (TGT) pada Pokok Bahasan Persamaan Kuadrat ditinjau dari Minat Belajar Siswa Kelas X SMA di Kabupaten Ngawi, Surakarta, Universitas Sebelas Maret, 2010.

Depdiknas (2006). Permendiknas No. 22 Tahun 2006 tentang Standar Isi. Jakarta, Depdiknas.

Gull, F. \& Shehzad, S.(2015). Effects of cooperative learning on students' academic achievement. Journal of Education and Learning, 9(3), 246-255.

Hainstock, E. G., (1999). Metode Pengajaran Montessori untuk Anak Prasekolah. Jakarta, Pustaka Delaprasta.

Hamidah,Q.G., Fadhilah,S.S. \& Adi,B.W. (2019). The development of thematic integrative based learning material for fifth grade elementary school. International Journal of Educational Research Review, 4 (1), 8-14.

Hartanto, P. (2011). Efektivitas Pembelajaran Matematika Kontekstual Audio Visual terhadap Pencapaian Belajar Matematika ditinjau dari Minat Belajar Siswa SMP Tahun Pelajaran 2010/2011. Surakarta, Universitas Sebelas Maret.

Hossain, A. \& Tarmizi, R. A.(2013), Effects of cooperative learning on student's achievement and attitudes in secondary mathematics. Procedia Social and Behavioral Sciences, 93, 473-77.

Mulyani, N. E.(2016). Keefektifan Model Tipe Course Review Horay Terhadap Hasil Belajar Ips Peserta Didik Kelas IV Sdn Gugus Drupadi Di Kecamatan Gunungpati Kota Semarang. Semarang, Universitas Negeri Semarang.

Pamungkas, S. R., \& Usodo, B.(2015). Eksperimentasi Model Pembelajaran Kooperatif Tipe Talking Stick dan Talking Bread pada Pokok Bahasan Geometri dan Pengukuran ditinjau dari Kecerdasan Majemuk Siswa Kelas VIII SMP Negeri Se-Kabupaten Karanganyar Tahun Pelajaran 2014/2015. Jurnal Elektronik Pembelajaran Matematika, vol/issue 2(8), 894-903. 
Meganingtyas,B.R., Winarni,R. \& Murwaningsih,T.(2019).The effect of using course review horay and talking stick learning methods towards social science learning result reviewed from learning interest.International Journal of Educational Research Review,4(2), 190-197. .

Purwanti,D., Gunarhadi \& Musadad,A.A. (2019). The effect of local-based 2013 curriculum implementation on students' environmental awareness. International Journal of Educational Research Review,4(1),65-75.

Rahimah, D. \& Syafdi ,M. (2014).The implementacion of cooperative learning course review horay type aided macromedia flash media in integral calculus course. Presented at International Seminar on Innovation in Mathematics and Mathematics Education 1st ISIM-MED 2014. Innovation and Technology for Mathematics and Mathematics Education. Departement of Mathematics Education,Yogyakarta State University, pp.115124.

Slameto (2013). Belajar dan Faktor-faktor yang Mempengaruhinya. Jakarta, Rineka Cipta.

Suprijono, A.(2010). Cooperative learning teori dan aplikasi PAIKEM. Yogyakarta, Pustaka Pelajar.

Vidayanti, R., Suyitno, Y. P. \& Listyarini, I.(2017). Keefektifan Model Talking Stick terhadap Hasil Belajar Matematika Siswa Kelas IV. Jurnal Pendas Mahakam, 2(3), 261-266. 